\title{
The Role of Fourwing Saltbush in Mined Land Rec- lamation: A Viewpoint
}

\author{
D. TERRANCE BOOTH
}

\section{Abstract}

Ease of establishment by direct seeding has resulted in fourwing saltbush [Atriplex canescens (Pursh) Nutt.] becoming the principal, sometimes the only, shrub on certain revegetated mined lands in Wyoming. To prevent dense stands that might exclude other shrub species, the Wyoming Department of Environmental QualityLand Quality Division, now limits the amount of fourwing saltbush that can be included in a reclamation seed mix. There is evidence that fourwing saltbush may aid, rather than hinder, the establishment of other shrubs. A thesis is developed for fourwing's role as a pioneer species that creates ecosystem diversity, auguments the invasion of late-succession plants, and declines in density as succession progresses. The shrub is recommended as a means to direct succession toward successful reclamation. Mine managers are cautioned that the rate of natural invasion of climax species into seeded stands of fourwing saltbush is not known.

Fourwing saltbush [Atriplex canescens (Pursh) Nutt.] is probably the most studied and most seeded of all western shrubs. The seed is relatively inexpensive and available from seed suppliers. Contrasted to other shrubs, successful stands are often established by direct seeding. This success, however, causes some to question its wide-spread use. Citing the need for plant diversity, Harju, staff biologist for the Wyoming Game and Fish Department, complained (1980) that, "The universal seed mix, three species of grasses and four-wing(sic) saltbush, is ... unacceptable for wildlife. ..."Wyoming Department of Environmental Quality-Land Quality Division (WDEQ/LQD) personnel, suggest that $A$. canescens seeded at 2.2 to $5.6 \mathrm{~kg} / \mathrm{ha}$, may exclude other shrubs and grow into monotypic stands (S. Tessmann, wildlife biologist, WDEQ/LQD, personal communication). Their 0.6-kg/ha pure-live-seed (Boles 1984) limitation emphasizes their concern about the relative success of this species on mined lands. Three areas are of concern when $A$. canescens is the major shrub component of a seed mix: (1) its forage value (2) its potential for competitive exclusion of other plants-particularly shrubs, and (3) its value to all types of wildlife.

The intent of this paper is to examine the role of $A$. canescens in the reclamation of mined lands. Particular attention is paid to the wildlife biologist's concern for loss of sagebrush habitat. The literature reviewed is a basis for postulating $A$. canescens' role as a pioneer shrub useful in accelerating and directing plant succession on mined lands. A case is thereby made for the unregulated use of $A$. canescens by reclamation specialists.

\section{Forage Value and Potential Toxicity}

The Range Plant Handbook (Dayton 1937) describes $A$. canescens as one of the most valuable forage shrubs for all classes of livestock and wildlife in the arid Southwest and Intermountain Region. The handbook attributes $A$. canescens' importance to its abundance, accessibility, size, large forage volume, evergreen habit, high palatability and nutritive value (citing work done 1900 through 1931 in New Mexico, Nevada and by the U.S. Dep. of Agriculture). The winter crude protein, in vitro digestibility, and production for 43 accessions of $A$. canescens (even-aged plants in a common garden) varied significantly among accessions with ranges of 6 to $14 \%$ for crude protein, 29 to $47 \%$ for digestibility, and

\footnotetext{
Author is range scientist, USDA-Agricultural Research Service, High Plains Grasslands Research Station, 8408 Hildreth Road, Cheyenne, Wyo. 82009.

Manuscript accepted March 25, 1985.
}

.05 to $2.0 \mathrm{~kg}$ for annual production per plant (Welch and Monsen 1984).

Yearling steers heavily use $A$. canescens on mine sites revegetated to native wheatgrasses (Agropyron spp.) in Shirley Basin, Wyoming (personal observation). A. canescens interseeded with crested wheatgrass (Agropyron desertorum Schult.) on Idaho rangeland was also readily eaten by cattle which consumed about $50 \%$ of the annual growth (Monsen 1980). Interplanting $A$. canescens in grass stands is recommended to increase yield and quality of forage (Van Epps and McKell 1977, Rumbaugh et al. 1982). $A$. canescens is reported as good forage for sheep (Nemati 1977a), goats, deer, elk, and rabbits (Plummer et al. 1968, Blauer et al. 1976, Wasser 1982) and fair for antelope (Wasser 1982). A number of birds and small mammals feed on both the seeds and the foliage (Anonymous 1968, Wasser 1982).

Palatability of Atriplex spp. may be related to the amount of salt accumulated on the leaf surface since the last precipitation event; if true, the physiological mechanism for salt tolerance also protects it against overbrowsing during drought periods (Goodin and Mozafar 1972 Wasser 1982).

As with most Atriplex species $A$. canescens, a secondary selenium absorber, will accumlate toxic selenium levels if grown on soils containing $2 \mu \mathrm{g} / \mathrm{g}$ or more of the element (Schmutz et al. 1968, Davis 1972). Davis (1972) notes that seleniferous soils are limited in the rangeland areas of the western U.S. and that the use of Atriplex spp. should not be curtailed because of selenium accumulation. Evidence gathered in Wyoming and Montana indicate reclaimed mined lands pose no greater threat of selenium toxicity than do the undisturbed range sites (Stanley et al. 1982).

\section{Potential for Competitive Exclusion}

In some southwestern deserts $A$. canescens may occur as a local dominant or a codominant; however, throughout most of its range it grows singly and more or less scattered among other members of the plant community (Dayton 1937, Wagner and Aldon 1978). $A$. canescens does not form extensive dominant stands as does big sagebrush [Artemisia tridentata (Nutt.)] or juniper (Juniperus spp.), nor is it reported to be aggressive. Yet $A$. canescens often dominates the mined land shrub population. This domination may be due to exclusive seeding, as noted by Harju (1980), to lack of survival of other seeded shrubs (personal observations at Hanna and at Shirley Basin, Wyo.) or to natural immigration as found by Wagner et al. (1978) in New Mexico. A. canescens domination, in each case, is due to its capability to prosper on disturbed land. Wagner and Aldon (1978) suggested, and presented evidence (Wagner et al. 1978), that $A$. canescens is an early-seral species as well as a constituent of mature ecosystems. If $A$. canescens functions as a pioneer plant, then relatively pure stands should give way-with time-to a more diverse shrub population. This has been observed on 2 revegetated mined sites in Wyoming where big sagebrush, rabbitbrush (Chrysothamnus spp.), Gardner's saltbush [Atriplex gardneri (Moq.) D. Dietr.], shadscale [A. confertifolia (Torr. and Fren.) Wats.] and fringed sagewort [Artemisia frigida (Willd.)] have immigrated, after 2 years, onto sites where $A$. canescens was the only shrub planted (Boles 1984). The immigration of these species contrasts with the limited success mine personnel have had establishing late-seral shrubs during initial planting programs (Stelter and Mikol 1981). 
The foregoing is direct, though tenative, evidence for $A$. canescens' role as a pioneer plant. It is sufficient basis for postulating that $A$. canescens can be used to accelerate succession on mined lands, that such acceleration will encourage natural immigration of late-seral shrubs such as sagebrush and rabbitbrush, and that the density of $A$. canescens stands will decrease as succession progresses. This thesis is supported by research of soil chemical and microbiological interactions with $A$. canescens and other shrubs, by documentation of $A$. canescens' affect on associated plants and by observations and research of $A$. canescens-decimating factors.

\section{Soil Effects}

A. canescens, and other shrubs, accelerate soil development. Soil profiles under shrubs are deeper, $\mathrm{pH}$ values more alkaline (Fairchild and Brotherson 1980), and N, P, K, (also S, Mg, Na, Ca, $\mathrm{Cl}, \mathrm{Zn}, \mathrm{Fe}, \mathrm{Mn}$, and $\mathrm{Cu}$ ), organic matter, rate of water infiltration, and microbiological activity are all higher under shrub canopies than under the interspaces (Charley 1972, Sharma and Tongway 1973, Tiedemann and Klemmedson 1973, Fairchild and Brotherson 1980, West 1981).

The level of microbiological activity is of special interest, since microorganisms are responsible for improvements in the chemical and physical character of the soil (Cundell 1977). The reestablishment of vesicular arbuscular mycorrhizae is a specific concern in the revegetation of mined lands, as adequate populations of these symbionts may be prerequiste to healthy stands of late-successional shrubs (Reeves et al. 1979, Loree and Williams 1982, Allen, E.B. 1984a). Plants colonizing disturbed lands are often nonmycorrhizal and may hinder recovery because they do not provide an inoculum source for mycorrhizal-obligate species (Reeves et al. 1979, Allen, E.B. 1984b Doerr et al. 1984). A. canescens can be infected (Williams et al. 1974, Aldon 1975, Lindsey 1984) and serve as a safe site for, and source of, mycorrhizal inoculum. Infection of $A$. canescens plants on mined land can occur through numerous avenues, including transportation of infected plant parts or mycelia fragments by wind, water or mammals (Hull 1981, MacMahon and Warner 1984). M.F. Allen (1984) observed that facultative mycorrhizal plants may be needed to build up organic matter and mycorrhizal inoculum prior to the establishment of mycorrhizaldependent species on mined land. $A$. canescens is uniquely capable of filling that need.

\section{Plant Effects}

The effects of $\boldsymbol{A}$. canescens on above-ground plant production are also noteworthy. Forage production increased three-fold after 1 million $A$. canescens seedlings were transplanted to the Central Plateau of Iran (Nemati 1977b). This increase was attributed largely to native grasses and forbs which benefited from the improved microclimate-especially protection from wind. Rumbaugh et al. (1982), who also found herbage production to be significantly greater for plants growing near $A$. canescens, credited the increase to better soil fertility near the shrubs.

A. canescens probably induces plant and animal diversity. The changes in soil character and in canopy-effected microclimatological factors (i.e., moisture, temperature, and wind) produce a continuum of plant niches between the shrub and the interspaces. This continuum is affected by and interacts with the overall pattern of shrub establishment and topography. The resulting array of niches would seem to favor a diversity of shrub-associated plant and animal species (Harju 1980, Reynolds and Trost 1980, Steele and Grant 1982; DePuit 1984).

\section{Decimating Factors}

At least two factors act as probable checks to the development of extensive pure stands of $A$. canescens. One is its palatability, which can lead to heavy browsing and, in some instances, to stand reduction (personal observation). Basal decay, apparently caused by a variety of endemic pathogens, may also limit the density of an $A$. canescens stand. The disease, which results in dieback and subsequent death of the plant (Van Epps 1974, Schnathorst and Davis 1978, Nelson and Welch 1984), is especially evident where $A$. canescens plants are grown close together (personal observation at the Soil Conservation Service Plant Materials Center, Aberdeen, Idaho; Nelson and Welch 1984).

\section{Value to Wildlife}

The preceding sections review the value of $A$. canescens as forage for big game, birds, and small mammals and as a factor in increasing production and creating diversity in the plant community. Perhaps the most important function of this fast-growing, pioneer shrub is as faunal cover (Anonymous 1968). As a cover plant, it is particularly useful for improving game-bird habitat on arid rangelands (Shaw et al. 1984). Because of ease of establishment and fast growth rate, $A$. canescens provides a woody plant component to the ecoystem several years sooner than slower-growing shrubs or shrubs requiring successionally mature soils for establishment. Significantly, Robinette (1972) found $A$. canescens to be used by the same number of wildlife species (22) as were found to use big sagebrush, a climax dominant.

Despite the documented value of $A$. canescens to wildlife, there are some problems. Foremost is the fact that sagegrouse, a major game species, has a winter diet that is almost $100 \%$ sagebrush. While $A$. canescens may aid the invasion of sagebrush by creating favorable microclimates for both the seedling and for supporting mycorrhizae, the process of succession will require time-perhaps as long as 20 years (though the observed invasion of nonseeded shrubs, including sagebrush, reported by Boles (1984) occurred within 2 years of the initial seeding). Some facts that impinge on the relative importance of sagebrush for sagegrouse habitat are: (1) sagegrouse will migrate 48 to $161 \mathrm{~km}$ from summer to winter range (Patterson 1952, Dalke et al. 1960, Hulet et al. 1984), (2) sagegrouse will nest under shrubs other than sagebrush (Hulet et al. 1984), (3) sagegrouse leks can be successfully moved (Roberson 1984), and (4) the spring (nesting), summer (brood rearing), and autumn diets are of forbs. The latter point is the reason the conversion of patches of sagebrush to forbs and grasses is a recognized method of sagegrouse habitat improvement (Rogers 1964, Roberson 1984).

A second problem may arise if browsing seriously limits $A$. canescens stature. Small or low growing plants do not provide enough cover or microclimate modification; therefore they are not "functional" in the sense of their expected contibution to the above-ground ecosystem.

A third problem, related to the rate of nonplanted-shrub invasion (with its associated diversity) may be postulated. Vigorous grass growth adjacent to, and stimulated by $A$. canescens may hinder shrub seedling establishment in the very microsites where success, otherwise, is most likely. This reasoning suggests that $A$. canescens should be seeded without grass where invasion by nonseeded shrubs is desired.

\section{Summary and Conclusions}

Daubenmire (1968) described pioneer plants as relatively xerophytic, light-demanding, heat-demanding, frost-hardy, deep-rooting, and not exacting as to soil. That $A$. canescens possesses these characteristics is well known and accounts for the shrub's widespread success on disturbed lands. Daubenmire (1968) further described pioneer plants as intolerant of later successional stages such that their tenure is normally limited to a single generation (after arrival of later stage conditions). Whether or not this latter characteristic is true for $A$. canescens is subject for debate and cause for concern by those charged with ensuring that postmining plant communities provide quality wild life habitat and meet specified criteria of production and species diversity and composition.

Observations and research indicate that $A$. canescens speeds 
succession and aids development of diverse plant communities. Conditions have been identified which may limit the density of the plant in late-seral stages. It therefore seems appropriate to recommend $A$. canescens as a means to direct mined land succession. Caution should be observed by mine operators since the rate of invasion by climax species into seeded stands of $A$. canescens is not known. However, the use of early-seral plants to direct succession is more efficient, less expensive (Schuman et al. 1980), and may allow succession to proceed faster than techniques which endeavor to force climax plants onto early-seral soils. In conclusion, the WDEQ/LQD limitation on $A$. canescens seeding rates is not needed and may be restricting a means for enhancing climax shrub immigration.

\section{Literature Cited}

Aldon, E.F. 1975. Endomycorrhizai enhance survival and growth of fourwing saltbush on coal mine spoils. USDA Forest Serv. Res. Note. RM-294.

Allen, E.B. 1984a. The role of mycorrhizae in the mined land diversity p. 273-295. In: Proceedings 3rd Symposium on Surface Coal Mining and Reclamation in the Great Plains. Billings, Mont.

Allen, E.B. 1984b. Mycorrhizae and colonizing annuals: implications for growth, competition, and succession. p. 41-51. In: S.E. Williams and M.F. Allen (eds.) VA Mycorrhizae and Reclamation of Arid and Semiarid Lands. Univ. Wyoming Agr. Exp. Sta. Laramie.

Allen, M.F. 1984. Physiology of mycorrhizae of arid zone plants: key to successful reclamation. p. 69-80. In:S.E. Williams and M.F. Allen (ed.). VA Mycorrhizae and Reclamation of Arid and Semiarid Lands. Univ. of Wyoming Agr. Exp. Sta. Laramie.

Anonymous. 1968. Atriplex - A cover plant for wildlife. Game Management Leaflet No. 11. Calif. Dep. of Fish \& Game. Sacramento, Calif.

Blauer, C.A., A.P. Plummer, E.D. McArthur, R. Stevens, and B.C. Giunta. 1976. Characteristics and hybridization of important intermountain shrubs. II. Chenopod Family. USDA Forest Serv. Res. Pap. INT-177. Intermtn. Forest and Range Exp. Sta. Ogden, Utah.

Boles, P.H. 1984. Reclamation of surface mined lands in Wyoming for livestock grazing and wildlife. p. 342-371. In: Proceedings 3rd Biennial Symposium on Surface Coal Mine Reclamation on the Great Plains, Billings, Mont.

Charley, J.L. 1972. The role of shrubs in nutrient cycling. p. 182-203. In: C.M. McKell, J.P. Blaisdell, and J.R. Goodin (eds.) Wildland shrubstheir biology and utilization. USDA Forest Serv. Gen. Tech Rep. INT-1. Intermtn. Forest and Range Exp. Sta., Ogden, Utah.

Gundell, A.M. 1977. The role of microorganisms in the revegetation of strip-mined land in the western United States. J. Range Manage. 30:299-305.

Dalke, P.D., D.B. Pyrah, D.C. Stanton, J.E. Crawford, and E. Schlatterer. 1960. Seasonal movements and breeding behavior of sage grouse in Idaho. Trans. 25th No. Amer. Wildlife Confer.

Daubenmire, R. 1968. Plant communities: A textbook of plant synecology. Harper and Row, New York.

Davis, A.M. 1972. Selenium accumulation in a collection of Atrixplex species. Agronomy J. 64:823-824.

Dayton, W.A. (Ld.) 1937. Range Plant Handbook. USDA Forest Serv. U.S. Gov. Printing Office.

DePuit, E.J. 1984. Potential topsoiling strategies for enhancement of vegetation diversity on mined lands. p. 258-272. In: Proceedings 3rd Symposium on Surface Coal Mining and Reclamation in the Great Plains. Billings, Mont.

Doerr, T.B., E.F. Redente, and F.B. Reeves. 1984. Effects of soil disturbance on plant succession and levels of mycorrhizal fungi in a sagebrushgrassland community. J. Range Manage. 37:135-139.

Fairchild, J.A., and J.D. Brotherson. 1980. Microhabitat relationships of six major shrubs in Navajo National Monument, Arizona. J. Range Manage. 33:150-156.

Goodin, J.R., and A. Mozafar. 1972. Physiology of salinity stress. p. 255-259. In: C.M. McKell, J.P. Blaidsdall, and J.R. Goodin (eds.) Wildland Shrubs-Their Biology and Utilization. USDA Forest Serv. Gen. Tech. rep. INT-1. Forest \& Range Exp. Sta., Ogden, Utah.

Hulet, B.V., J.T. Flinders, J.S. Green and R.B. Munay. 1984. Seasonal movements and habitat selection of sage grouse in southeastern Idaho. Abstract p. 11. Third Annual Wildland Shrub Symposium. The Biology of Artemisia and Chrysothamnus. Provo, Utah.

Hull, C. 1981. Biota of bentonite mine spoil. M.S. Thesis Colorado State Univ.
Harju, H.J. 1980. Reclamation for wildlife-the Wyoming viewpoint. p. 25(1)-25(7). In: Proceedings Symposium on Adequate Reclamation of Mined Lands, Billings, Mont.

Lindsey, D.L. 1984. The role of vesicular-arbuscular mycorrhizae in shrub establishment. p. 52-67. In: S.E. Williams and M.F. Allen (eds.) VA Mycorrhizae and Reclamation of Arid and Semiarid Lands. Univ. of Wyoming. Agr. Exp. Sta. Laramie.

Loree, M.A.J., and S.E. Williams. 1982. Endomycorrhizal colonization of a surface mine. p. 10-63. In: Effect of chemical seed treatments, Mycorrhizae, Rhizobium and pelleting of shrub seeds used in disturbed land reclamation report on coop. Agreement No. 58-8AHZ-9-467 USDAARS-High Plains Grasslands Res. Sta.

MacMahon, J.A., and Warner, N. 1984. Dispersal of mycorrhizal fungi: processes and agents. p. 28-41. In: S.E. Williams and M.F. Allen (eds.) VA mycorrhizae and reclamation of arid and semiarid lands. Univ. of Wyoming, Agr. Exp. Sta. Laramie.

Monsen, S.B. 1980. Interseeding fourwing saltbush (Atriplex canescens Pursh Nutt.) with crested wheatgrass (Agropyron desertorum Schult.) on southern Idaho rangelands. Abstract. p. S1. Soc. for Range Manage., 33rd Annual Meeting, San Diego, Calif.

Nelson, D.L., and B.L. Welch. 1984. Basal decay of fourwing saltbush Atriplex canescens. Abstract No. 268. Abst. Soc. for Range Manage., 37th Annual Meeting, Rapid City, S.D.

Nemati, Nasser. 1977a. Comparative palatability of Atriplex canescens. J. Range Manage. 30:368-369.

Nemati, Nasser. 1977b. Shrub transplanting for range improvement in Iran. J. Range Manage. 30:148-150.

Patterson, R.L. 1952. The sage grouse of Wyoming. Wyoming Game and Fish Comm.

Plummer, A.P., D.R. Christensen, and S.B. Monsen. 1968. Restoring big game range in Utah. Utah Div. Fish \& Game. Publ. 68-3.

Reeves, F.G., D. Wagner, T. Moorman, and J. Kiel. 1979. The role of endomycorrhizae in revegetation practices in the semi-arid west. I. A comparison of incidence of mycorrhizae in several disturbed vs. natural environments. Amer. J. Bot. 66:6-13.

Reynolds, T.D., and C.H. Trost. 1980. The response of native vertebrate populations to crested wheatgrass planting and grazing by sheep. $J$. Range Manage. 33:122-125.

Roberson, J.A. 1984. An overview of current sagegrouse-sagebrush relationships. Abstract. p. 12. Third Annual Wildland Shrub SymposiumThe Biology of Artemisia and Chrysothamnus. Provo, Utah

Robinette, W.L. 1972. Browse and cover for wildlife. p. 69-76. In: C.M. McKell, J.P. Blaisdell, and J.R. Goodin (eds.) Wildland Shrubs-their biology and utilization. USDA Forest Serv. Gen. Tech. Rep. INR-1. Intermtn. Forest and Range Exp. Sta., Ogden, Utah.

Rogers, G.E. 1964. Sagegrouse investigation in Colorado. Game Res. Div. Tech. Publ. No. 16. Colorado Fish and Parks Dep. Denver, CO.

Rumbaugh, M.D., D.A. Johnson, and G.A. Van Epps. 1982. Forage yield and quality in a Great Basin shrub, grass and legume pasture experiment. J. Range Manage. 35:604-609.

Schmutz, E.M., B.N. Freemann, and R.E. Reed. 1968. Livestock-poisoning plants of Arizona. Univ. of Arizona Press, Tucson.

Schnathorst, W.C., and J.R. Davis. 1978. Susceptibility of native desert plants to Verticillium dahliae. Phytopathology News 12:205 Proc. Annual Meeting of Amer. Phytophatological Soc. (Abstract).

Schuman, G.E., E.M. Taylor, Jr., F. Rauzi, and G.S. Howard. 1980. Standing stubble versus crimped straw mulch for establishing grass on mined lands. J. Soil and Water Conserv. 35:25-27.

Sharma, M.L., and D.J. Tongway. 1973. Plant induced soil salinity patterns in two saltbush (Atriplex sp.) communities. J. Range Manage. 26:121-125.

Shaw, N., A. Sands, and D. Turnipseed. 1984. Potential use of fourwing saltbush [Atriplex canescens (Pursh) Nutt.] and other dryland shrub accessions for upland game bird cover in southern Idaho. In: A.R. Tiedemann, K.L. Johnson, E.D. McArthur, S.B. Monsen and H. Stutz (compilers). Proc. The Biology of Atriplex canescens and Related Chonopods. USDA Forest Serv. Gen. Tech. Rep. INT-172. Intermtn. Forest and Range Exp. Sta., Ogden, Utah.

Stanley, M.A., G.E. Schuman, F. Rauzi, and L.I. Painter. 1982. Quality and element content of forages grown on three reclaimed mine sites in Wyoming and Montana. Reclamation and Revegetation Research 1:311-326.

Steele, B.B., and C.V. Grant. 1982. Topographic diversity and islands of natural vegetation: aids in re-estabishing bird and mammal communities on reclaimed mines. Reclamation and Revegetation Res. 1:367-382. 
Stelter, L.H., and S.A. Mikol. 1981. Introduction to proceedings. In; Stelter, L.H., E.J. DePuit, and S.A. Mikol (Tech. Coordinators) Shrub Establishment on Disturbed Arid and Semi-arid Lands. Wyoming Game and Fish Dep., Laramie.

Tiedemann, A.R., and J.O. Klemmedson. 1973. Nutrient availability in desert grassland soils under mesquite (Prosopis juliflora) trees and adjacent open areas. Soil Sci. Soc. Amer., Proc. 37:107-111.

Van Epps, G.A., and C.M. MeKell 1977. Shrubs plus grass for livestock forage: a possibility. Utah Sci. 38:75-78.

Van Epps, G.A. 1974. Shrub seed production-a potential enterprise. Utah Sci. 35:21-23.

Wagner, W.L., and E.F. Aldon. 1978. Manual of the saltbushes (Atriplex spp.) in New Mexico. USDA Forest Serv., General Tech. Rep. RM-57 Rocky Mtn. Forest \& Range Exp. Sta., Fort Collins, Colo.
Wagner, W.L., W.C. Martin, and E.F. Aldon. 1978. Natural succession on strip-mined lands in northwestern New Mexico. Recl. Rev. 1:67-73.

Wasser, C.H. 1982. Ecology and culture of selected species useful in revegetating disturbed lands in the West. Western Energy and Land Use Team, Fish \& Wildlife Service, Washington, D.C.

Welch, B.L., and S.B. Monsen. 1984. Winter nutrient value of 43 accessions of fourwing saltbush (Atriplex canescens) grown on a uniform garden. In: A.R. Tiedemann, K.L. Johnson, E.D. McArthur, S.B. Monsen and H. Stutz (compilers). Proceedings-The Biology of Atriplex canescens and Related Chenopods. USDA Forest Serv., Gen. Tech. Rep. INT-172. Intermtn. Forest and Range Exp. Sta., Ogden, Utah.

West, N.E. 1981. Nutrient cycling in desert ecosystems. p. 301-324. In: D.W. Goodall, R.A. Perry, K.M.W. Howes (eds.). Arid-land Ecosystems vol. 2. Cambridge Univ. Press.

Williams, S.E., A.G. Wollum, and E.F. Aldon. 1974. Growth of Atriplex canescens (Pursh.) Nutt. improved by formation of vesicular-arbuscular mycorrhizae. Proc. of the Soil Sci. Soc. of Amer. 38:962-965. 